\title{
FALO, OBJETO $a$ E FANTASIA: CONTRIBUIÇÕES DE JACQUES LACAN NA CLÍNICA COM CRIANÇAS
}

Franciele Gisi Martins de Almeida

Esta pesquisa partiu de uma investigação sobre a articulação entre falo e objeto $a$, a partir da elaboração freudiana sobre o complexo de Édipo, com as contribuições de Lacan sobre a metáfora paterna. Em seguida, buscou-se investigar em Lacan o objeto $a$ e o modo como este ressitua o falo, a castração e, consequentemente, o Édipo. Finalmente, buscou-se extrair algumas consequências clínicas da fantasia, como articulação entre sujeito e objeto, na construção de uma resposta frente ao enigma do desejo do Outro.

BANCA:

Marcus André Vieira (Orientador)

Ana Lucia Lutterbach Holck

Silvia Maria Abu-Jamra Zornig

Data da defesa: 19/03/2010 